\title{
HUBUNGAN KONFORMITAS DENGAN PERILAKU KONSUMTIF PADA SUPORTER SEPAKBOLA SEMEN PADANG F.C
}

\author{
Amin Akbar, Tuti Rahmi, Yolivia Irna \\ aminakbar@fip.unp.ac.id
}

\section{Departement of Psychology, Faculty of Education, Universitas Negeri Padang}

\begin{abstract}
This study aims to determine the relationship between conformity and consumptive behavior at football supporters of Semen Padang FC. This type of research is quantitative correlation with 70 subject which are Spartacks football supporters who were in Padang city. Subject retrieval is using incidental techniques. The data is processed by using a Product Moment Correlation technique. The hypothesis test results prove that there is a significant positive correlation between conformity with consumptive behavior at Semen Padang FC football supporters. There is a very significant positive relationship between conformity and consumptive behavior So it is advisable to football supporters to selective in buying the football attribute, both in quality and quantity
\end{abstract}

Keywords: Conformity, consumptive behavior, supporter

\begin{abstract}
Abstrak Penelitian ini bertujuan untuk mengetahui hubungan antara konformitas dengan perilaku konsumtif pada kelompok suporter sepakbola Semen Padang FC. Jenis penelitian yang digunakan adalah Kuantitatif korelasional dengan subjek 70 orang Spartacks yang berada di kota Padang. Pengambilan subjek menggunakan teknik incidental. Data diolah menggunakan teknik korelasi Product Moment. Hasil pengujian hipotesis membuktikan bahwa terdapat korelasi positif yang signifikan antara konformitas dengan perilaku konsumtif pada suporter sepakbola Semen Padang FC. Terdapat hubungan positif yang sangat signifikan antara konformitas dengan perilaku konsumtif sehingga disarankan kepada suporter sepakbola agar selektif dalam membeli atribut sepakbola, baik secara kualitas maupun kuantitas.
\end{abstract}

Kata Kunci: Konformitas, perilaku konsumtif, suporter 


\section{Pengantar}

Sepakbola merupakan cabang olahraga paling populer dan paling digemari di seluruh dunia. Pernyataan tersebut barangkali tidak terbantahkan, bahkan rasanya tidak diperlukan sebuah penelitian ilmiah untuk mendapatkan pengesahan atas pernyataan tersebut. Untuk memberikan bayangan tentang popularitas sepakbola, lebih dari 2 biliun pemirsa televisi menyaksikan kesebelasan Brazil mengalahkan Italia pada final World Cup 1994. Ini dapat dibandingkan dengan jumlah pemirsa yang menyaksikan NFL Super Bowl sekitar 750 juta pada tahun 1993, 350 juta menyaksikan final tenis Wimbledon, dan 490 juta menyaksikan pendaratan manusia pertama di bulan (Joseph, 1999). Data di atas dapat menggambarkan betapa populernya olahraga sepakbola di atas bumi ini.

Sepakbola juga menjadi olahraga yang universal, karna setiap orang dapat memainkan olahraga paling popular ini. Sepakbola juga menjadi olahraga yang paling di gemari oleh masyarakat, tua, muda, kaya ataupun miskin semua pasti tahu akan sepakbola. Pada dewasa ini sepakbola tidak hanya digemari dan dimainkan oleh kaum adam saja tetapi kaum hawa juga sangat banyak yang menggemari sepak bola, seperti yang terjadi di Olympico Roma

dimana stadion banyak di isi oleh wanitawanita cantik (Shalahuddin, 2014).

Pada dasarnya sepak bola hanya dimainkan oleh dua tim yang beranggotakan sebelas orang dalam masing masing tim tetapi dalam dunia sepak bola juga dikenal dengan

pemain kedua belas yang sering di sebut juga dengan suporter, pemain kedua belas dilapangan bukan berarti hanya sebagai tukang sorak di stadion tetapi pemain kedua belas disini memiliki arti yang dalam yaitu memang harus mampu menjadi penyemangat bagi tim yang sedang berkerja keras di lapangan (Marajo, 2012). Suryanto (2008) berpendapat bahwa supporter sepakbola merupakan kelompok sosial yang berada dalam suatu situasi tertentu, yaitu situasi pertandingan sepakbola yang tidak hanya menyaksikan pertandingan tetapi juga memberikan dukungan kepada tim yang difavoritkan dengan yel-yel dan nyanyian lainya serta menggunakan atribut tertentu, sementara penonton hanya sekedar menyaksikan pertandingan saja. Para supporter melambangkan identitas mereka dengan atribut-atribut sepakbola dari team yang didukung. Atribut tersebut meliputi kaos, syal, bendera, topi, dan stiker yang menjadi barang-barang paling diminati dan banyak dicari oleh para suporter sepakbola (Bawono, 2010).

Menurut Sumartono (dalam Putri, 2013) banyaknya ragam produk yang dipasarkan mempengaruhi sikap seseorang terhadap pola pembelian, sehingga pemenuhan kebutuhan saat ini tidak lagi digunakan untuk memenuhi kebutuhan (need), melainkan lebih pada keinginan (want). Perilaku demikian cenderung lebih mengarahkan individu pada orientasi yang lebih memacu pada aspek-aspek materil atau dengan kata lain individu cenderung kearah perilaku konsumtif. Perilaku konsumtif sebagai tindakan membeli barang bukan untuk mencukupi kebutuhan tetapi untuk memenuhi keinginan, yang dilakukan secara berlebihan sehingga menimbulkan pemborosan dan inefisiensi biaya (Suyasa \& Fransisca, 2005).

Hal tersebut sesuai dengan penelitian tentang perilaku konsumtif yang dilakukan oleh Astuti (2013), dalam berbelanja subjek penelitiannya selalu bertindak berlebihan artinya barang yang mereka beli tidak hanya satu barang saja tetapi lebih dari itu, selain itu subjek juga selalu membeli barang baru walaupun barang yang ada atau yang mereka pakai masih terbilang barang bagus dan belum ada kerusakan sama sekali. Setiap membeli barang subjek selalu memperhatikan secara teliti model maupun warna pada barang yang akan mereka beli, bila mereka melihat barang yang mereka sukai mereka cenderung bertingkah heboh dan setelah membeli barang yang mereka sukai terlihat ekspresi gembira dan senang dari wajah subjek tersebut. Hasil dari keseluruhan subjek 
penelitian, dapat diketahui bahwa para subjek dalam penelitian ini membeli barang berdasarkan atas dasar kesukaan dan ketertarikan terhadap model barang yang terlihat menarik, melakukan pembelian barang tanpa adanya perencanaan, membeli barang atas pertimbangan harga serta tidak mempertimbangkan manfaat maupun kegunaan, membeli barang dengan harga yang mahal atau barang dengan merek ternama akan menimbulkan rasa percaya diri yang tinggi, membeli barang dengan jenis sama namun dari merek yang berbeda, membeli barang demi menjaga penampilan diri dan gengsi, serta membeli barang untuk menjaga simbol status.

Penelitian lain mengenai perilaku konsumtif dilakukan oleh Rinata (2010) menunjukan bahwa tingkat pendidikan perpengaruh terhadap perilaku konsumtif, dimana semakin rendah tingkat pendidikan masyarakat maka akan cenderung berperilaku konsumtif, dan sebaliknya semakin tinggi tingkat pendidikan masyarakat maka akan cenderung tidak berperilaku konsumtif. Lingkungan sosial juga ditemukan dapat mempengaruhi perilaku konsumtif, dimana semakin tinggi tingkat interaksi sosial masyarakat maka akan cenderung berperilaku konsumtif, dan sebaliknya semakin rendah tingkat interaksi sosial masyarakat maka akan cenderung tidak berperilaku konsumtif.

Selain beberapa faktor yang didapat dari hasil penelitian tersebut, faktor lain yang juga dapat mempengaruhi perilaku konsumtif menurut Suyasa \& Fransisca (2005) adalah konformitas. Sarwono (dalam Putri, 2013) menjabarkan konformitas sebagai bentuk perilaku sama dengan orang lain yang didorong oleh keinginan sendiri. Adanya konformitas dapat dilihat dari perubahan perilaku atau kenyakinan karena adanya tekanan dari kelompok, baik yang suguhsunguh ada maupun yang dibanyangkan saja. Deaux (dalam Cipto \& Kuncoro, 2009) menambahkan bahwa konformitas berarti tunduk pada kelompok meskipun tidak ada permintaan langsung untuk mengikuti apa yang telah diperbuat oleh kelompok.
Konformitas pada supporter
sepakbola ini dapat dilihat dalam pertandingan final piala AFF Suzuki tahun 2010 antara Indonesia melawan Malaysia pada tanggal 29 desember 2010, dimana lebih dari seratus ribu suporter dengan menggunakan seragam tim nasional Indonesia yang berwarna merah-merah menjelma menjadi lautan manusia dan mengumandangkan lagu kebangsaan Indonesia Raya di stadion Utama Gelora Bung Karno (vivanews.com. 2010). Jadi dapat dilihat bahwa karna adanya tekanan untuk memakai baju tim nasional dalam menyaksikan pertandingan tersebut sehingga seseorang melakukan hal tersebut agar dapat disetarakan dengan anggota kelompok dan diakui oleh kelompok lainya yaitu kelompok suporter tim nasional Indonesia.

Hasil penelitian yang dilakukan oleh Cipto dan Kuncoro (2009) yang melihat konformitas dengan perilaku minumminuman keras menunjukkan bahwa makin tinggi konformitas terhadap kelompok maka makin tinggi perilaku minum-minuman beralkohol pada remaja, demikian sebaliknya. Selain itu Maukar (2013) menemukan dalam penelitiannya bahwa semakin tinggi konformitas seseorang maka brand loyality juga akan semakin tinggi.

Berdasarkan hasil wawancara, observasi serta hasil penelitian yang telah dijelaskan di atas bahwa perilaku konsumtif dapat dipengaruhi oleh konformitas maka peneliti tertarik untuk mengangkat judul penelitian Hubungan Konformitas Dengan Perilaku Konsumtif Pada Supporter Sepakbola.

\section{Landasan Teori}

\section{Perilaku konsumtif dan konformitas}

Menurut Lina dan Rosyid (1997) perilaku konsumtif adalah kehidupan mewah yang berlebihan, penggunaan segala hal yang dianggap paling mahal sehingga identik dengan pemborosan dan memberikan kepuasan dan kenyamanan fisik yang berlebihan. Perilaku tentunya tidak akan lepas dari lingkungan dan keadaan individu 
itu sendiri. Sehingga dapat disimpulkan bahwa perilaku dapat terjadi karna adanya stimulus dan rangsangan dari lingkungan ataupun dari diri individu tersebut. Perilaku konsumtif tersebut dapat ditandai dengan adanya Pembelian Impulsif (Impulsive buying), pemborosan (Wasteful buying) dan mencari kesenangan (Non-rational buying).

Terdapatnya dorongan sosial bagi individu dalam menentukan apa yang akan ia beli untuk kebutuhan atau keinginanya dapat disebut sebagai konformitas. Menurut Baron \& Byrne (2005), menyatakan bahwa konformitas adalah bertingkah laku dengan cara-cara yang dipandang wajar atau dapat diterima oleh kelompok atau masyarakat. Sarwono (2005) juga menjelaskan bahwa mengapa seseorang melakukan konformitas yaitu disebabkan oleh keinginan untuk memenuhi norma yaitu disebabkan oleh keinginan untuk memenuhi keinginan dan harapan orang lain sehingga dapat diterima oleh orang lain. Konformitas sendiri ditandai dengan adanya pengaruh sosial normatifdan pengaruh social informasional.

\section{Metode}

Pendekatan yang digunakan dalam penelitian ini adalah pendekatan kuantitatif. Data yang dikumpulkan berupa data kuantitatif atau jenis data lain yang dapat dikuantifikasikan, dan diolah dengan menggunakan teknik statistik (Yusuf, 2010).

Pendekatan kuantitatif yang
digunakan dalam penelitian ini adalah penelitian kuantitatif korelasional. Penelitian korelasional merupakan jenis penelitian yang melihat hubungan antara satu atau beberapa ubahan dengan satu atau beberapa ubahan lain (Yusuf, 2010). Dengan demikian penelitian korelasional ini akan dapat memprediksi hubungan antara variabel bebas dan variabel terikat, dimana variabel bebas dalam penelitian ini adalah konformitas dan variabel terikatnya adalah perilaku konsumtif membeli atribut sepakbola.

Subjek dalam penelitian ini adalah Spartacks atau Suporter Padang dan Anak rantau Cinta Kabau Sirah yang berada di Kota Padang yang berjumlah 70 orang dengan teknik pengambilan sampel dengan cara Incidental atau yang sering disebut dengan teknik kebetulan dengan syarat harus memiliki kartu keanggotaan Spartacks.

Teknik penggumpulan data yang digunakan dalam penelitian ini berupa instrument, dengan menggunakan skala psikologi tuntuk kedua variabel yaitu skala perilaku konsumtif dan skala konformitas. Skala psikologi terdiri dari item-item favourable dan unfavourable yang bertujuan untuk menghindarai stereotip jawaban. Item favourable merupakan item atau pernyataan yang mendukung objek sikap, sedangkan item unfavourable merupakan item atau pernyataan yang tidak mendukung objek sikap. Jenis skala yang digunakan pada penelitian ini adalah skala Likert, yaitu skala yang menjadikan distribusi respons sebagai dasar penentuan nilai skalanya.

Skala prilaku konsumtif dibuat berdasarkan aspek prilaku konsumtif menurut Lina dan Rosyid (1997). Skala ini terdiri atas 23 aitem, dengan menggunakan 4 pilihan jawaban Sangat Tidak Sesuai (STS), Tidak Sesuai (TS), Sesuai (S), dan Sangat Sesuai (SS), diberi skor 1 sampai dengan 4.

Kemudian skala konformitas dibuat berdasarkan aspek konformitas menurut Baron dan byrne (2005) Skala ini terdiri atas 25 aitem, dengan menggunakan 4 pilihan jawaban Sangat Tidak Sesuai (STS), Tidak Sesuai (TS), Sesuai (S), dan Sangat Sesuai (SS), diberi skor 1 sampai dengan 4.

Analisis data yang digunakan dalam penelitian ini yaitu analisis Uji Korelasi. Winarsunu (2004) menyatakan bahwa teknik Uji Korelasi digunakan untuk mengetahui hubungan antara variabel bebas dengan variabel terikat. Uji korelasi yang digunakan yaitu korelasi Product Moment untuk menggambarkan hubungan antara 2 buah variabel yang sama-sama berjenis interval atau rasio. Data kemudian diolah dengan bantuan program SPSS 16.0. for Windows.

\section{4 | Psychophedia Jurnal Psikologi Universitas Buana Perjuangan Karawang}




\section{Hasil}

Berdasarkan penelitian yang dilakukan didapatkan hasil uji normalitas sebaran variabel perilaku konsumtif diperoleh nilai K-SZ sebesar 0.762 dan nilai Asymp. Sig (2-tailed) sebesar $0.607 \quad(p>0.05)$. Variabel konformitas diperoleh nilai K-SZ sebesar 0.962 dan nilai Asymp. Sig (2-tailed) sebesar $0.313 \quad(\mathrm{p}>0.05)$. Uji normalitas menunjukkan bahwa kedual variabel dalam penelitian ini terdistribusi normal. Jadi data penelitian ini bisa dianalisis dengan statistik parametrik karena telah memenuhi syarat berdistribusi normal.

Hasil uji linearitas pada penelitian ini menyatakan bahwa nilai linieritas pada konformitas dengan perilaku konsumtif adalah sebesar $F=24.880$ yang memiliki $p$ $=0,000(\mathrm{p}<0.01)$, dengan demikian berarti asumsi linier dalam penelitian ini terpenuhi. Berdasarkan hasil analisis korelasi yang dilakukan, hubungan konformitas dengan perilaku konsumtif diperoleh koefisien korelasi $\left(r_{e}\right)$ sebesar 0.513, $p=0.000(p<0.05)$ menandakan hipotesis diterima.

Berdasarkan hasil uji korelasi yang peneliti lakukan, maka dapat disimpulkan bahwa Terdapat korelasi positif yang sangat signifikan antara konformitas dengan perilaku konsumtif pada suporter sepakbola. Semakin positif konformitas suporter sepakbola maka semakin tinggi tingkat perilaku konsumtifnya dalam membeli atribut sepakbola. Hal ini berarti hipotesis yang diajukan diterima kebenarannya.

\section{Diskusi}

Berdasarkan hasil penelitian yang dilakukan ditemukan bahwa subjek dalam penelitian ini secara umum memiliki tingkat konformitas yang rendah. Secara kategorisasi subjek penelitian berada pada kategori sedang hal ini disebabkan karna sebagian besar dari subjek penelitan ini berada pada usia masa dewasa awal yaitu sebanyak 54 subjek, sedangkan konformitas yang paling tinggi itu terjadi pada masa remaja hal ini sesuai dengan penelitian Berndt, dkk (dalam Santrock, 2002) yang menyatakan bahwa pada masa remaja konformitas terjadi dengan frekuensi yang lebih tinggi dibandingkan dengan masa pertumbuhan lainnya. Hal tersebut dapat dimengerti mengingat pada masa remaja proses pemantapan diri sedang berlangsung sehingga remaja akan lebih rentan terhadap pengaruh perubahan dan tekanan yang ada disekitarnya. Sears dkk (1985) berpendapat bahwa ketaatan remaja terhadap norma kelompok, kepercayaan yang besar terhadap kelompok, perasaan takut terhadap penyimpangan norma kelompok dan perasaan takut jika mendapat celaan dari lingkungan sosialnya mendukung remaja untuk melakukan konformitas yang tinggi.

Selain itu, bentuk dedikasi individu yang memiliki konformitas terhadap tim sepakbola tidak hanya dilihat dari pembelian atribut-atribut tim saja. Hal ini terlihat dari suporter sepakbola yang rela mengorbankan waktu, tenaga dan uang demi tim yang dibela (Prasetyo, 2011). Hasil penelitian yang dilakukan oleh Lucky dan Setyowati (2013) terhadap suporter Persebaya Bonek, menemukan bahwa konformitas ditunjukkan dengan (1) mendukung Persebaya kapanpun dan di manapun bertanding; (2) loyalitas tanpa batas; (3) Bonek: lambang keberanian sebagai representatif perilaku; (4) bagimu Persebaya, bagimu Indonesia; (5) demokrasi ala suporter Bonek. Selain itu, juga diketahui beberapa faktor penyebab perilaku konformitas Bonek antara lain: konteks sosial, pendidikan, usia, identitas kultur budaya "arek", ekonomi, media massa, serta lingkungan baik dari keluarga, teman, dan masyarakat. Perilaku konformitas Bonek juga disebabkan oleh pemain, pelatih, wasit, dan penonton serta keterlibatan pemimpin dalam komunitas.

Dalam penelitian ini juga ditemukan bahwa subjek memiliki perilaku konsumtif yang rendah secara umumnya. Namun, sama halnya dengan konformitas secara kategorisasi subjek dalam penelitian ini berada pada kategori sedang. Hal ini dapat disebabkan karna sebagian besar subjek dari penelitian ini berjenis kelamin laki-laki yaitu sekitar 60 orang $(85.7 \%)$ dan hanya menyisakan 10 orang subjek perempuan (14.3\%) dengan kata lain subjek dalam

\section{5 | Psychophedia Jurnal Psikologi Universitas Buana Perjuangan Karawang}


penelitian ini mayoritas laki-laki, sesuai dengan penelitian yang dilakukan oleh Febrianto (2012) yang menyatakan bahwa tingkat konsumtif pada wanita lebih besar daripada laki-laki. Hasil ini juga diperkuat oleh penelitian yang dilakukan oleh Hotpascaman (2010), berdasarkan jenis kelamin subjek penelitian didapatkan hasil subjek dengan jenis kelamin wanita memiliki tingkat konsumtif yang tinggi dibandingkan dengan laki-laki. Didalam penelitian ini mayoritas subjek berjenis kelamin laki-laki $(85.7 \%)$, sehingga hasil penelitian ini sejalan dengan penelitian sebelumnya. Hal lain yang dapat mempengaruhi perilaku konsumtif pada penelitian ini yaitu pekerjaan, Pekerjaan juga dapat mempengaruhi perilaku konsumtif seseorang dimana orang yang bekerja akan memiliki penghasilan sendiri dan akan lebih konsumtif dibandingkan dengan mahasiswa dan pelajar yang masih meminta uang saku kepada orang tuanya, hal ini sejalan dengan penelitian yang dilakukan oleh Alawiyah (2009) mengatakan bahwa bagi mereka yang memiliki pekerjaan tidak tetap, cenderung tidak berperilaku konsumtif. Tapi bagi mereka yang memiliki pekerjaan yang tetap, mereka akan berperilaku konsumtif. Seperti diketahui subjek dalam penelitian ini mayoritas berstatus sebagai mahasiswa 51 orang dan pelajar 8 orang., sedangkan hanya 11 orang dari subjek penelitian ini yang memiliki pekerjaan tetap.

Hasil uji korelasi menentukan bahwa adanya korelasi positif yang sangat signifikan antara konformitas dengan perilaku konsumtif pada suporter sepakbola. Secara umum kekuatan korelasi antara konformitas dan perilaku konsumtif pada suporter Semen Padang FC berada pada taraf yang sedang, hal ini disebabkan subjek pada penelitian kali ini mayoritas berada pada usia dewasa awal dan berjenis kelamin pria serta berprofesi sebagai mahasiswa. Ini dapat dilihat dari gambar 2, 3 dan 4, dimana mean empiris yang paling tinggi terdapat pada subjek yang berjenis kelamin wanita, dan berada pada usia dewasa awal serta subjek yang sudah memiliki pekerjaan.
Penelitian membuktikan bahwa tidak semua orang memiliki konformitas dan perilaku konsumtif yang sama. Sebagian orang lebih mudah untuk berkonformitas dan memiliki perilaku konsumtif. Hal ini sesuai dengan Penelitian yang dilakukan oleh Hollander dan Julian (dalam Zikmund, dkk 1984) menunjukkan bahwa ada kecenderungan yang lebih besar bagi perempuan untuk melakukan konformitas dibanding dengan laki-laki. Senada dengan pendapat tersebut, penelitian yang dilakukan Cruthchfield (dalam Zikmund, dkk 1984) menemukan bahwa perempuan lebih cenderung melakukan konformitas di dalam kelompok dibanding laki-laki. Peran gender juga berpengaruh dalam perilaku konsumtif, dimana wanita memang lebih konsumtif dibandingkan pria seperti penelitian yang dilakukan oleh Febrianto (2012) yang menyatakan bahwa tingkat konsumtif pada wanita lebih besar daripada laki-laki.

\section{Kesimpulan}

Berdasarkan hasil penelitian yang telah dilakukan dan pengujian hipotesis mengenai hubungan konformitas dengan perilaku konsumtif pada suporter sepakbola Semen Padang FC, maka dapat ditarik kesimpulan sebagai berikut:

1. Suporter Semen Padang FC berada pada kategori konformitas yang sedang.

2. Suporter Semen Padang FC juga memiliki tingkatan perilaku konsumtif yang sedang.

3. Terdapat hubungan positif yang sangat signifikan antara konformitas dengan perilaku konsumtif.

\section{Saran}

Berdasarkan hasil penelitian ada beberapa saran yang dikemukakan oleh peneliti. Beberapa saran tersebut antara lain:

1. Bagi peneliti lainnya yang akan meneliti tentang topik yang sama disarankan untuk menggunakan metode pengumpulan data maupun metode penelitian yang berbeda agar dapat memperkaya kajian-kajian mengenai

\section{6 | Psychophedia Jurnal Psikologi Universitas Buana Perjuangan Karawang}


perilaku konsumtif. Selain itu peneliti yang akan mengembil topik yang sama juga disarankan untuk melakukan untuk penelitian lebih lanjut terhadap variabelvariabel lain yang mempengaruhi perilaku konsumtif.

\section{Kepustakaan}

Alawiyah. (2009). Mall dan perilaku konsumtif masyarakat muslim ambarukmo. Skripsi. Fakultas Ushuluddin: Universitas Islam Negeri Sunan Kalijaga, Yogyakarta.

Astuti, E. D. (2013). Perilaku konsumtif dalam membeli barang pada ibu rumah tangga di kota samarinda. eJournal Psikologi, 1(2), 148-156.

Baron, R. A., \& Byrne, D. (2005). Psikologi sosial jilid 2 edisi kesepuluh. Alih bahasa oleh Ratna Djuwita, dkk. Jakarta: Erlangga.

Bawono, M. T. (2010). Peluang Usaha Bisnis Merchandise Sepak Bola Mulai Diminati. Edisi 4 Mei 2010. http://www.timlo.net/baca/1793/bisni s-merchandise-sepak-bola-mulaidiminati/ diakses pada 2 Oktober 2014.

Cipto., \& Kuncoro, J. (2009). Harga diri dan konformitas terhadap kelompok dengan perilaku minum minuman beralkohol pada remaja. Proyeksi, $5(1)$.

Febrianto, F. (2012). Perbedaan perilaku konsumtif pada pria dan wanita dewasa awal yang sudah menikah dan masih lajang. Skripsi. Fakultas Psikologi: Universitas Gunadarma

Hotpascaman., \& Irmawati. (2010). Hubungan Antara Perilaku Konsumtif Dengan Konformitas pada Remaja. Medan: Fakultas psikologi Universitas Sumatera Utara.
2. Bagi para suporter sepakbola Semen Padang FC agar lebih selektif dalam membeli atribut sepakbola, baik secara kualitas maupun kuantitas.

Joseph, A. L. (1999). "Sepakbola Taktik dan Teknik Bermain”. Jakarta: PT Raja Grafindo Persada.

Lina., \& Rosyid, H. F. (1997). Perilaku Konsumtif Berdasarkan Locus of Control Pada Remaja Putri. Jurnal Pemikiran dan Penelitian Psikologi. 1(4).

Lucky, N., \& Setyowati, N. (2013). Fenomena perilaku fanatisme suporter sepak bola (studi kasus komunitas suporter persebaya bonek di surabaya). Kajian Moral dan Kewarganegaraan, 1(1), 180-196.

Marajo, R dalam Goal.com. (2012, 19 mei), dua tahun spartacks balita itu makin loyal, dari http://www.goal.com/idID/news/298 0/indonesianpremierleague/2012/05/ 19/3112853/dua-tahun spartacksbalita-itu-makin-loyal diakses pada 1 desember 2014

Maukar. (2013). Hubungan konformitas dan identitas sosial dengan brand loyality pada merek starbucks coffee. Calyptra: Jurnal Ilmiah Mahasiswa Universitas Surabaya, 2(2).

Prasetyo, P. D. (2011). Interaksi sosial dalam komunitas suporter sepakbola pasoepati solo. Skripsi. Fakultas Ilmu Sosial dan Politik: UNESA.

Putri, A. M. (2013). Kematangan emosi dengan perilaku konsumtif pada pria metroseksual. Jurnal Online Psikologi. 1(2).

Putri, K. R. (2013). Hubungan antara identitas sosial dan konformitas dengan perilaku agresi pada suporter 
sepakbola persisam putra samarinda. eJournal Psikologi, 1(3).

Rinata. (2010). Hubungan antara tingkat pendidikan dan lingkungan sosial dengan perilaku konsumtif masyarakat desa tumpak kepuh, kecamatan bakung, kabupaten blitar. Malang: Universitas Negeri Malang.

Santrock, J. W. (2002). Life span development, (edisi 5). Jakarta: Erlangga.

Sears, D. O. dkk. (1985). Psikologi Sosial Edisi Kelima Jilid 2. Alih bahasa oleh Michael Adryanto. Jakarta: Erlangga.

Shalahuddin dalam Sindonews. (2014,23 September) bila olimpico identik dengan wanita cantik, dari http://soccer.sindonews.com/read/90 4438/62/bila-olimpico-identikdengan wanita-cantik-1411470537 diakses pada 1 desember 2014

Suryanto. (2008). Perbedaan istilah antara penonton dengan suporter sepak bola. Dari http://suryanto.unair.ac.id./2008/01/0 9/perbedaan-istilah-antara penonton dan-suporter-sepakbola/diakses pada 4 Desember 2014

Suyasa, P \& Fransisca. (2005). Perbandingan Perilaku Konsumtif Berdasarkan Metode Pembayaran. Phronesis, 7(2)

Vivanews.com. (2010, 31 desember), suporter garuda luar biasa. Dari http://fokus.news.viva.co.id/news/rea d/196706-permainan-hebat-timnasmendewasakan-suporter. Diakses pada 24 november 2014

Yusuf, A. M. (2010). Metodologi penelitian: dasar-dasar penelitian ilmiah. Padang: UNP Press.

Winarsunu, T. (2004). Statistik dalam penelitian psikologi dan pendidikan. Malang: UMM Press.

Zikmund, W. G., Sciglimpaglia D., Lundstrom, J, W., \& Cowell, G, D. 1984. The effects of gender and product stereotyping on conformity judgements: an experiment. Advance in Consumer Research, 11, 265-26 